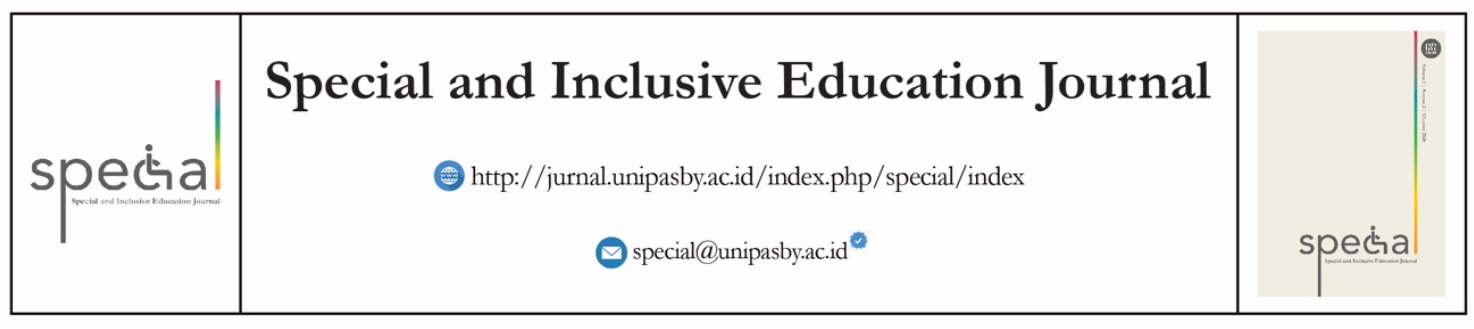

\title{
Efektivitas Metode DR Kawashima dalam Meningkatkan Kemampuan Matematika Anak Autis
}

\section{Endro Tri Susdarwono}

susdarwonoendrotri@gmail.com

Program studi S1 Ilmu Komunikasi - Universitas Peradaban

Jalan Raya Pagojengan KM 3, Paguyangan, Brebes

\begin{tabular}{|c|c|}
\hline Artikel Info & Abstrak \\
\hline $\begin{array}{l}\text { Koresponden penulis : } \\
\text { Endro Tri Susdarwono } \\
\text { anayuliati@stkippgri-bkl.ac.id }\end{array}$ & $\begin{array}{l}\text { Penelitian ini bertujuan untuk menguji efektivitas metode DR Kawashima dalam } \\
\text { meningkatkan kemampuan matematika anak penyandang autis. Autisme atau } \\
\text { autism spectrum disorder (ASD) merupakan gangguan perkembangan pada anak yang } \\
\text { menyebabkan kemampuan komunikasi dan sosialisasi anak terganggu. Dalam } \\
\text { penelitian ini metode yang digunakan adalah eksperimen. Karakteristik penelitian } \\
\text { eksperimen dalam penelitian ini meliputi: manipulasi, pengendalian atau control, } \\
\text { dan pengamatan. Desain kuantitatif yang akan digunakan dalam penelitian ini } \\
\text { berupa desain penelitian eksperimen The one-group pretest-posttest design. Pengujian } \\
\text { yang digunakan dengan memakai uji t untuk sampel nonindependen dan uji beda } \\
\text { t-test dengan sampel berhubungan SPSS. Hasil penelitian eksperimen ini } \\
\text { mengungkapkan bahwa metode latihan otak DR Kawashima mampu } \\
\text { meningkatkan kemampuan matematika siswa yang menyandang status autis. Hal } \\
\text { ini bisa dilihat baik dengan perhitungan uji-t sampel nonindependen maupun uji } \\
\text { beda t-test dengan sampel berhubungan SPSS, didapatkan bahwa hipotesis nol } \\
\text { ditolak dan menerima hipotesis alternatif, dimana dinyatakan bahwa kedua } \\
\text { kelompok berbeda secara signifikan. }\end{array}$ \\
\hline 0100 & 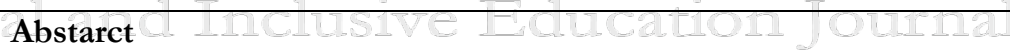 \\
\hline $\begin{array}{l}\text { Keywords: } \\
\text { DR Kawashima method } \\
\text { Autism, Math Skills }\end{array}$ & $\begin{array}{l}\text { This study aims to test the effectiveness of the DR Kawashima method in } \\
\text { improving the math skills of children with autism. Autism or autism spectrum } \\
\text { disorder (ASD) is a developmental disorder in children that causes children's } \\
\text { communication and socialization skills to be impaired. In this study, the method } \\
\text { used was experimental. The characteristics of experimental research in this study } \\
\text { include: manipulation, control, and observation. The quantitative design used in } \\
\text { this study is an experimental research design called the one-group pretest-posttest } \\
\text { design. The test used is the t-test for non-independent samples and the t-test with } \\
\text { different samples related to SPSS. The results of this experimental study revealed } \\
\text { that Dr. Kawashima's brain training method was able to improve the mathematical } \\
\text { abilities of students with autistic status. This can be seen both by the calculation of } \\
\text { the non-independent sample t-test and the different t-test with SPSS-related } \\
\text { samples, it was found that the null hypothesis was rejected and accepted the } \\
\text { alternative hypothesis, where it was stated that the two groups were significantly } \\
\text { different. }\end{array}$ \\
\hline
\end{tabular}




\section{PENDAHULUAN}

Pendidikan membantu anak supaya kelak anak itu cakap menyelesaikan tugas hidupnya atas tanggung jawab sendiri (Sadulloh, 2015). Sedangkan menurut Henderson, pendidikan merupakan suatu proses pertumbuhan dan perkembangan, sebagai hasil interaksi individu dengan lingkungan sosial dan lingkungan fisik, berlangsung sepanjang hayat sejak manusia lahir. Warisan sosial merupakan bagian dari lingkungan masyarakat, merupakan alat bagi manusia untuk pengembangan manusia yang terbaik dan intelegen, untuk meningkatkan kesejahteraan hidupnya (Henderson, 1959). Terdapat beberapa prinsip dasar tentang pendidikan yang akan dilaksanakan: pertama, bahwa pendidikan berlangsung seumur hidup. Usaha pendidikan sudah dimulai sejak manusia lahir dari kandungan ibunya, sampai tutup usia, sepanjang ia mampu untuk menerima pengaruh dan dapat mengembangkan dirinya. Suatu konsekuensi dari konsep pendidikan sepanjang hayat adalah, bahwa pendidikan tidak identik dengan persekolahan. Pendidikan akan berlangsung dalam lingkungan keluarga, sekolah, dan masyarakat. Kedua, bahwa tanggung jawab pendidikan merupakan tanggung jawab bersama semua manusia: tanggung jawab orang tua, tanggung jawab masyarakat, dan tanggung jawab pemerintah. Pemerintah tidak boleh memonopoli segalanya. Bersama keluarga dan masyarakat, pemerintah berusaha semaksimal mungkin agar pendidikan mencapai tujuan yang telah ditetapkan. Ketiga, bagi manusia pendidikan merupakan suatu keharusan, karena dengan pendidikan manusia akan memiliki kemampuan dan kepribadian yang berkembang, yang disebut manusia seluruhnya. Henderson mengemukakan bahwa pendidikan pada dasarnya suatu hal yang tidak dapat dielakkan oleh manusia, suatu perbuatan yang "tidak boleh" tidak terjadi, karena pendidikan itu membimbing generasi muda untuk mencapai suatu generasi yang lebih baik, dan hal ini juga tidak terkecualikan bagi anak penderita autis.

Menurut Permendiknas No 22 bahwa matematika diperlukan dalam bidang teknologi yang dilandasi oleh perkembangan matematika di bidang aljabar, analisis, teori peluang dan matematika diskrit (Yuharsono, 2018). Menurut Martini dan Jamaris bahwa matematika merupakan bidang studi yang perlu dipelajari karena hakikat matematika adalah pemahaman terhadap pola perubahan yang terjadi di dunia nyata dan di dalam pikiran manusia serta keterkaitan pola-pola tersebut secara holistik (Dwidarti, et. Al, 2019). Menurut Fauzi, et.al, (2019) dengan belajar matematiika beberapa kemampuan siswa akan terlatih seperti kemampuan berpikir logis, analitis, sistematis, kritis, kreatif dan mengasah kemampuan menyelesaikan masalah dan bekerjasama. Walaupun matematika sangat penting untuk dipelajari dan dikuasai siswa, namun tidak dapat dipungkiri bahwa matematika memiliki sifat abstrak yang menjadi salah satu sebab matematika sulit untuk dipahami siswa (Yenni \& Sukmawati, 2019). Hal ini juga berlaku terhadap siswa yang menyandang status autis. Oleh karena itu, siswa perlu diberikan pemahaman tentang pentingnya arti belajar, manfaat belajar, bagaimana mencapainya, sehingga siswa akan mengerti tentang kegunaan materi pelajaran maematika dalam kehidupannya (Zakiah, et.al, 2019). Menurut Irmawati et.al (2019) untuk mempelajari matematika tidaklah cukup hanya mengenal konsep, namun dapat menggunakan konsep tersebut untuk 
menyelesaikan masalah, baik massalah yang ada kaitannya dengan matematika maupun permasalahan yang dijumpai dalam kehidupan sehari-hari.

Autisme atau autism spectrum disorder (ASD) merupakan gangguan perkembangan pada anak yang menyebabkan kemampuan komunikasi dan sosialisasi anak terganggu. Gejala autisme sangat beragam dan tiap anak yang menderita kondisi ini dapat menunjukkan gejala yang berbeda (Nugraheni, 2012). Namun, secara umum, ciri-ciri anak autis terdiri dari 3 karakteristik utama, yaitu: 1) Masalah komunikasi, antara lain sulit bicara, menulis, membaca, dan memahami bahasa isyarat, seperti menunjuk dan melambai. Hal ini kemudian membuatnya sulit untuk memulai percakapan dan memahami maksud dari suatu perkataan atau petunjuk yang diberikan orang lain. 2) Gangguan dalam berhubungan sosial, anak dengan autisme sering kali terlihat asyik dengan dunianya sendiri, sehingga sulit terhubung dengan orang-orang di sekitarnya. Terkadang anak dengan autisme juga terlihat kurang responsif atau sensitif terhap perasaannya sendiri atau pun orang lain. 3) Gangguan perilaku,

Kendati demikian, gejala autisme tidak selamanya buruk. Beberapa anak dengan autisme ada yang memiliki kelebihan atau bakat di bidang tertentu, seperti mampu belajar secara rinci lalu mengingatnya untuk waktu yang lama dan tertarik mempelajari seni musik dan menggambar. Terhadap anak penyandang autisme, diperlukan suatu penelitian dan eksperimen untuk meningkatkan kemampuan mereka. Salah satu yang dapat diterapkan adalah pelatihan otak dengan menggunakan metode DR Kawashima.

Menurut Prof Ryuta Kawashima cara terbaik merangsang kemampuan otak adalah dengan mengerjakan perhitungan matematika yang gampang dengan cepat dan membaca dengan keras. Didapati bahwa dua aktivitas ini bahkan dapat membantu orang mempertahankan kejernihan daya pikir dan menghilangkan kepikunan (Kawashima, 2009). Metode pelatihan tersebut diciptakan untuk membantu meremajakan otak dan mengembangkan fungsi otak ke tingkat yang lebih tinggi. Walaupun demikian kekuatan otak dapat dipertahanankan agar tidak memburuk dengan merangsang otak setiap hari. Metode latihan otak yang diciptakan oleh Kawashima mengaktifkan bagian terbesar otak. Latihan kesehatan otak meningkatkan penyaluran oksigen, darah, dan berbagai macam asam amino ke otak bagian cortex. Hailnya lebih banyak urat syaraf dan sambungan urat syaraf yang menandakan otak sehat.

Metode latihan otak DR Kawasima terdiri dari 1) latihan menghitung, tes ini mengevaluasi fungsi umum prefrontal cortex di belahan kiri dan kanan otak. Penelitian Kawashima membuktikan bahwa hasil tes menghitung seperti ini berkaitan erat dengan kemampuan matematika setiap orang. 2) tes menghafal kata, tujuan tes ini adalah mengevaluasi aktivitas prefrontal cortex di belahan kiri yang terhubung dengan daya ingat jangka pendek. 3) tes mengasah otak, tujuan tes ini adalah mengevaluasi fungsi umum bagian prefrontal cortex di kanan atau kiri belahan otak. Penelitian Kawashima membuktikan bahwa membaca dengan keras, menyelesaikan perhitungan mudah, dan menulis adalah cara mengakaktifkan otak yang efektif. 
Penelitian ini bermaksud untuk menerapkan latihan otak metode DR Kawashima terhadap siswa penyandang autisme atau autism spectrum disorder (ASD) dengan melihat efektivitas metode DR Kawashima dalam meningkatkan kemampuan matematika anak autis.

\section{METODE PENELITIAN}

Dalam penelitian ini metode yang digunakan adalah eksperimen. Metode eksperimen adalah suatu metode penelitian yang berusaha mencari hubungan variabel tertentu terhadap variabel lain dalam kondisi yang terkontrol secara ketat (Sugiyono, 2003). Sementara itu, Arikunto (2006) mengemukakan bahwa metode eksperimen adalah suatu cara untuk mencari hubungan sebab akibat (hubungan kausal) anara dua faktor yang sengaja ditimbulkan oleh peneliti dengan mengeliminasi atau mengurangi atau menyisihkan faktor-faktor lain yang mengganggu. Desain kuantitatif yang akan digunakan dalam penelitian ini berupa desain penelitian eksperimen The one-group pretest-posttest design. Desain ini digunakan karena dalam penelitian ini terdapat suatu kelompok yang diberi perlakuan (treatment) yaitu siswa yang menyandang autisme, kemudian bermaksud untuk membandingkan keadaan sebelum dengan sesudah diberi perlakuan. Dengan demikian, hasil perlakuan dapat diketahui lebih akurat jika dibandingkan dengan desain sebelumnya. Paradigma dalam penelitian diilustrasikan sebagai berikut:

Tabel 1. Tabel The one-group pretest-posttest design

\begin{tabular}{ccc}
\hline Pre-test & Perlakuan & Post-test \\
\hline 0 & $\mathrm{X}$ & $0_{1}$
\end{tabular}

Teknik sampling yang digunakan untuk desain ini adalah purposive sampling. Purposive sampling adalah teknik penentuan sampel dengan pertimbangan tertentu. Pertimbangan dalam mengambil sampling adalah penelitian dimaksudkan khusus untuk meneliti siswa yang menyandang status autisme setingkat Sekolah Dasar di Kabupaten Pemalang.

\section{HASIL DAN PEMBAHASAN}

Penelitian ini bertujuan untuk menguji perbedaan efektivitas metode DR Kawashima dalam meningkatkan kemampuan matematika anak autis yang dikenakan pada suatu kelompok yang dibentuk dengan penjodohan kasus atau penyeimbangan kasus. Pengujian yang digunakan adalah uji$t$ untuk sampel nonindependen. Sampel nonindependen adalah sampel yang dibentuk melalui penjodohan. Sampel penjodohan yang sempurna adalah kelompok sama yang dipakai pada waktu yang tidak bersamaan (satu kelompok yang menerima dua treatment pada waktu yang berbeda). Individu anggota sampel dalam penelitian ini tidak dipilih secara random. Situasi untuk dapat menetapkan signifikansi perbedaan antara mean kelompok tidak ditarik secara random karena individu-individu kelompok yang dipasangkan dipilih atas dasar satu karakteristik yaitu siswa 
penyandang autisme. Treatment atau perlakuan diberikan dalam waktu 60 hari. Kemudian dilakukan pembandingan antara nilai pretest dan postesnya.

Uji-t untuk sampel nonindependen digunakan untuk melihat apakah dua kelompok nilai tersebut berbeda secara signifikan. Satu kelompok, masing-masing terdiri dari 5 siswa Sekolah Dasar penyandang status autisme. Untuk menetapkan signifikansi perbedaan antara mean kelompok nilai tersebut perlu dihitung koefisien korelasi antara skor-skor pretest dan postest.

Rumus uji-t untuk sampel non independent:

$$
t=\frac{M_{D}}{\sqrt{\frac{\sum D^{2}-\frac{\left(\sum D\right)^{2}}{n}}{n(n-1)}}} d f=n-1
$$

Tingkat kebebasan dicari dengan rumus $n-1$, jumlah pasangan dikurangi satu. Apabila nilai t hitung sama dengan atau lebih besar dibanding harga $\mathrm{t}$ tabel, peneliti menolak hipotesis nol; mean-mean berbeda secara signifikan pada suatu tingkat signifikansi yang dipilih. Berikut data nilai pretest dan postes dari hasil penelitian siswa disajikan melalui tabel 1:

Table 1. Nilai Pretest dan Postest

\begin{tabular}{cc}
\hline Nilai pretest & Nilai postest \\
\hline 2 & 4 \\
3 & 5 \\
4 & 4 \\
5 & 8 \\
6 & 9 \\
\hline
\end{tabular}

Perhitungan uji-t untuk sampel nonindependen dalam penelitian ini. Rumus yang digunakan sesuai dengan formula 1. D adalah simbol yang baru; D singkatan dari "defference." D adalah beda antara skor pasangan-pasangan yang dijodohkan. Jadi, masing-masing $\mathrm{D}$ sama dengan $\mathrm{M}_{1}-\mathrm{M}_{2}$. Untuk data di atas beda skor pasangan yang pertama adalah $2-4=-2$. Berikut disajikan dalam tabel 2, yang merupakan tabel kerja. Setelah menghitung D setiap pasangan nilai dan sekaligus menghitung kuadrat dari D, jumlah dan mean dari D (MD) dapat kita peroleh. Mean dari D dihitung dengan cara yang sama ntuk mean yang lain, dengan menambahkan masing-masing $\mathrm{D}$ dan membagi dengan jumlah individu. 
Table 2. Tabel Kerja Uji-t untuk Sampel Non-Independen

\begin{tabular}{cccc}
\hline $\mathbf{X}_{\mathbf{1}}$ & $\mathbf{X}_{\mathbf{2}}$ & $\mathbf{D}$ & $\mathbf{D}^{\mathbf{2}}$ \\
\hline 2 & 4 & 2 & 4 \\
3 & 5 & 2 & 4 \\
4 & 4 & 0 & 0 \\
5 & 8 & 3 & 9 \\
6 & 9 & 3 & 9 \\
& & & \\
\hline
\end{tabular}

$$
M D=\frac{\sum D}{n} M D=\frac{10}{5} M D=2
$$

Setelah semua komponen didapatkan, maka substitusikan bilangan-bilangan tersebut pada rumus t.

$$
t=\frac{M_{D}}{\sqrt{\frac{\sum D^{2}-\frac{\left(\sum D\right)^{2}}{n}}{n(n-1)}}}=\frac{2}{\sqrt{\frac{26-\frac{10^{2}}{5}}{5(5-1)}}}=\frac{2}{\sqrt{\frac{26-20}{5(4)}}}=\frac{2}{\sqrt{\frac{6}{20}}}=\frac{2}{\sqrt{0,3}}=3,65
$$

Jadi, t-hitung $=3,65$. Dengan $\alpha=0,05$ maka sebelum menggunakan tabel, kita mmerlukan df. Untuk ujit sampel non-independen rumus tingkat kebebasan (df) adalah $\mathrm{n}-1$, jumlah pasangan dikurangi $1, \mathrm{df}=5-1=4$. Jadi, kita memperoleh $\mathrm{t}=3,65 ; \alpha=0,05 ; \mathrm{df}=4$. Sekarang dengan mempergunakan tabel t kita dapat mendapatkan nilai t tabel. nilai tabel-t yang diperlukan untuk menolak hipotesis nol adalah 2,776 (nilai kritis). Karena 3,65 $\geq 2,776$, sehingga kita menolak hipotesis nol dan menerima hipotesis alternatif yang berarti bahwa kedua kelompok berbeda secara signifikan.

Sedangkan untuk pengujian uji statistik dengan SPSS digunakan uji beda t-test dengan sampel berhubungan (related samples). Dari output SPSS terlihat bahwa rata-rata nilai pretest kelompok sebesar 4,00 dan rata-rata nilai postest kelompok setelah diterapkan medote latihan otak metode DR Kawashima sebesar 6,00. Hasil tersebut dapat dilihat pada tabel 3.

Table 3. Uji Beda t-test dengan Sampel Berhubungan

\begin{tabular}{rllll}
\hline Nilai & Mean & N & Std. Deviation & Std. Error Mean \\
\hline Pretest & 4,00 & 5 & 1,58114 & 0,70711 \\
Postest & 6,00 & 5 & 2,34521 & 1,04881 \\
\hline
\end{tabular}

Table 4. Uji Beda t-test dengan Sampel Berhubungan

\begin{tabular}{llll}
\hline & $\mathrm{t}$ & $\mathrm{df}$ & Sig. \\
\hline Pretest-Postest & 3,651 & 4 & 0,022
\end{tabular}


Perbedaan nilai ini signifikan secara statistik terlihat dari tabel 4, nilai t statistic 3,651 yang lebih besar dari t-tabel $5 \%=2,776$. Didapatkan bahwa hipotesis nol ditolak dan menerima hipotesis alternatif, dimana dinyatakan bahwa kedua kelompok berbeda secara signifikan

\section{KESIMPULAN}

Berdasarkan hasil penelitian yang telah diuraikan, maka kesimpulan dari penelitian eksperimen ini adalah metode latihan otak DR Kawashima mampu meningkatkan kemampuan matematika siswa autis. Hal ini bisa dilihat baik dengan perhitungan uji-t sampel nonindependen maupun uji beda t-test dengan sampel berhubungan SPSS, didapatkan bahwa hipotesis nol ditolak dan menerima hipotesis alternatif, dimana dinyatakan bahwa kedua kelompok berbeda secara signifikan. Ini menunjukkan bahwa metode tersebut memiliki tingkat efektivitas untuk meningkatkan kemampuan matematika siswa yang menyandang status autis.

\section{DAFTAR PUSTAKA}

Arikunto, S. (2006). Prosedur Penelitian Suatu Pendekatan Praktik. Jakarta: Rineka Cipta.

Dwidarti, U., Mampouw, Lygia, H. \& Setyadi, D. (2019). Analisis kesulitan siswa dalam menyelesaikan soal cerita pada materi himpunan. Jurnal Pendidikan Matematika, 3(2), 315-322.

Fauzi, A., Waluya, B., \& Masrukan. (2019). Pembelajaran matematika dengan pendekatan realistic mathematics education (RME) berbasis soal open-ended untuk meningkatkan komunikasi. Phenomenon, 9(1), 87-98.

Fraenkel, J.R., Wallen, N.E., \& Hyun, H.H. (2012). How to Design and Evaluate Research in Education. United States (New York): McGraw-Hill Companies. Inc.

Sugiyono. (2010). Metode Penelitian Bisnis (Pendekatan Kuantitatif, Kualitatid dan R\&D). Bandung: Alfabeta.

Henderson, Stella vn Pettern. (1959). Introduction to Philosophy of Education. Chicago: The University of Chicago.

Irmawati, Rukli, \& Bharllah. (2019). Pengembangan perangkat pembelajaran matematika menggunakan metode discovery learning berbasis grander di sekolah dasar. Edumaspul: Jurnal Pendidikan, 3(2), 127-139.

Kawashima. (2009). Latih Otak. Anda Lagi. Jakarta: Mitra Media.

Lestari, Karunia Eka \& Yudhanegara, Mokhammad Ridwan. (2015). Penelitian Pendidikan Matematika. Bandung: PT Refika Aditama.

Nugraheni, S.A. (2012). Menguak Belantara Autisme. Buletin Psikologi 20(1-2), 9-17.

Sadulloh, Uyoh. (2015). Pengantar Filsafat Pendidikan. Bandung: Alfabeta. 
Yenni, \& Sukmawati, R. (2019). Analisis kemampuan berpikir reflektif matematis berdasarkan minat belajar pada mata kuliah sruktur aljabar. Teorema: Teori dan Riset Matematika, 4(2), 75-82.

Yuharsono. (2018). Pengembangan perangkat pembelajaran aritmetika social dengan pendekatan matematika realistic dan model belajar kooperatif tipe stad. Penelitian Matematika dan Pendidikan Matematika, 1(2), 92-106.

Zakiah, N.e., Sunaryo, Y., \& Amam, A. (2019). Implementasi pendekatan kontekstual pada model pembelajaran berbasis masalah berdasarkan langkah-langkah polya. Teorema: Teori dan Riset Matematika, 4(2), 111-120. 